\title{
EXPLORING STUDENTS' LEARNING STRATEGIES IN SPEAKING PERFORMANCE
}

\author{
Ahmad Wael \\ Universitas Muhammadiyah Sorong, West Papua, Indonesia \\ Email:ahmadwael818@gmail.com \\ Muhammad Nur Ashar Asnur \\ Universitas Negeri Makassar, Makassar, Indonesia \\ Email: ashar.lingusitik@gmail.com \\ Ibrahim Ibrahim \\ Universitas Muhammadiyah Sorong, West Papua, Indonesia \\ Email: ibrahim080988@gmail.com
}

DOI: 10.26858/ijole.v2i1.5238

\begin{abstract}
This article aims to explore learning strategies used by students in speaking performance. To identify the types of learning strategies were adopted by the students of English department in learning to speak, the authors prepared journal logs with specific questions related to learning strategies. The researchers used qualitative design in this research. The result of this research showed that students of the third semester of English department frequently used memory strategies in learning speaking. The second was metacognitive strategies followed by social strategy in the third rank. The fourth was affective strategies and compensation strategies in the fifth rank and followed by cognitive strategy in the sixth rank. Furthermore, the other factors also influence students' learning strategies in learning speaking such as psychological factor, the role of teacher, task, environment and social factors. The roles of the lecturer as a feedback provider, a participant, and a prompter.
\end{abstract}

Keywords: Learning strategies, speaking performance.

\section{INTRODUCTION}

Most students of English department try to employ different strategies to learn speaking skill. Thus, learning strategies are necessary to build students' motivation and help them to be independent in learning English (Jones, 1998). Moreover, students at university levels sometimes do not feel confident to speak English either inside or outside the classroom even though they are from English department. The main point that should be considered that the students arer lack of exposure and practice in English. These conditions bring students to sustain their desire in learning speaking. Furthermore, the researcher wish to explore the learning strategies which are used by the students at the third semester of English department in a private university in Sorong.

Some researchers had investigated the use of strategies in their learning. Kemala (2014), who held a study concerning the analysis of independent learning strategies used senior high students, found that students frequently use to apply memory strategies in their learning. The second is social strategies followed by cognitive and metacognitive 
strategies in four ranks. Moreover, the students do not use affective and compensation strategies in their learning. Furthermore, Gursoy (2010) who investigated students' learning strategies employed by third, fourth and fifth grade in two private schools in Turkey, found that students employed memory strategies, cognitive strategies, compensation strategies, metacognitive strategies, and social strategies. Chen (2014) also conducted a study concerning students' learning strategies in age differences; found that students employed oxford theory concerning learning strategies. The result of studies, however, it can be stated that students need to choose their learning strategies to make them aware in case of their learning. Learning strategies allow the learners to learn independently to become autonomous learners.

Chamot (1987), "learning strategies are techniques, approaches or thoughtful actions that students take to the learning and recall both linguistic and content area information." In other words, strategies are the way or actions that the students have in preparing them for their learning. Moreover, Wenstein and Mayer (1986) also emphasized concerning learning strategies that "learning strategies as the behaviors and thoughts that a learner used in during learning that intended to influence the learner's encoding process." It means that learning strategies can also be viewed in the manner and critical idea which are used by the students to help them in sustaining and influencing their learning process.

Furthermore, Wenden (1991) stated that: “...Learner strategies refer to language learning behaviors; learners involve in to learn and manage the learning of a second language, what they know about the strategies they use. What they know about the parts of their language learning other than the strategies they use". In other words, learners identifying learning strategies not only as techniques, methods, ways or goals to help the students in establishing or creating their learning but also learning approaches can be considered as the behavior and critical thought that learners used in comprehending the process of learning. Some other points that can be accomplished towards learning strategies should include communication strategies or language use. Firstly, the policies that learners use are to connect the meaning when he or she sometimes finds the difficulty in learning the language. Secondly, learners' strategies are approachable skills and process such as, memorizing, practicing, preparing oneself to speak, organizing one's learning, etc.

Oxford (1990) emphasized that learning strategies consist of direct strategy; direct strategies cover memory strategies, cognitive strategies, and compensation strategies while indirect strategies cover metacognitive, affective, and social strategies. Moreover, other factors also influence students' learning strategies in students' speaking performance. As stated by Ellis and Sinclair (1998) that 'raising learners' awareness of learning strategies is not enough on its own, learners also benefit from reflecting on the various factors which affect their learning." In other words, it is not enough to raise students' awareness on learning strategies towards their learning, but it is necessary also influenced by various factors to their knowledge to be able to learn on their way of learning to become independent learners.

In encouraging students' awareness and motivation to learn to speak, the teacher or lecturer should have some roles to provide adequate teaching which can get students to speak English. Therefore, Harmer (2001) proposed three positions of the teacher which have particular relevance when the teacher is trying to get students to talk fluently; it covers prompter, participant and feedback provider.

Speaking can be considered as the productive skill of the oral communication which involves other people in conveying the information by pronunciation the words. Besides speaking is taught in academic level, 
speaking is also used to deliver the idea which aims to gain the knowledge. Learners need to be able to know English orally to enhance their English competence because, in common sense of people's viewing, speaking is one of the crucial parts. Nation and Newton (2009) define speaking "as part of work, or academic study may include presenting reports or presenting a viewpoint on a particular topic

\section{METHODS \\ Research Design}

This descriptive qualitative research was designed to explore the strategies are employed by the students in speaking performance, the factors influence students' learning strategies and the roles that the lecturer does in enhancing students' speaking performance. The writer used qualitative design to obtain the data and to present the result of this research.

\section{Setting and Participants}

This research was conducted in the third semester of English department at the University of Muhammadiyah Sorong. This research was held in November 2015 - January 2016 which was only taken from speaking class.

The participants were students of English department on the third semester. The participants consist of 12 students from a different class; there were two classes than six students were represented from each class. This research only focused on speaking subject which took their grade to classify the participants.

\section{Data Collection Method}

In this research, the researcher did some steps in data collecting technique to obtain the comprehensive data. First, document baseddata (students' journal) were distributed to the students after each meeting in speaking class, the total students' journal was twelve for twelve students as the participants of this research.
The researcher prepared the questions on the journal, and the journals were given to the students in every meeting. The students were asked to fulfill that journal concerning the strategies they used in speaking performance with the topic which discusses in each session. The issue presented in the meeting was based on the syllabus.

Second, the interview based-data as the second instrument; the interview was conducted to gain the detail data concerning the objective was to find out the factors influencing students' learning strategies and the roles that the lecturer does in speaking performance. The students were asked based on the interview guidelines with some questions to get the data from the participants as needed by the researcher.

Third, the questionnaire based-data as the secondary data was used to obtain and to support the interview concerning the objective of third research question was to discover the roles that lecturer does in enhancing students' speaking performance. The questionnaire was distributed to the total twelve students as the participants of this research. The questionnaire was adapted from Arafat about "the roles of English teachers." The participants were asked to fill out the questionnaire by answering five type of answers containing highly agreed, agreed, hesitate, disagreed and remarkably disagreed

\section{Data Analysis}

The data from the students' journal were collected and analyzed qualitatively through some procedures. First, the students' journals were collected at the end of each meeting. Second, data were tabulated in accordance and analyzed them systematically concerning the objective of the first research question which contains students' learning strategies as their own learning that is done by the students in speaking class.

The data from interview guidelines were transcribed and sort them into Microsoft sheet, 
and then the researcher classified them into each item to discover the objective of second and third research question concerning the factors that influenced the students' learning strategies and the roles that lecturer does in speaking performance.

Also, the data from the questionnaire were also tabulated and sort them to each item to support the data from an interview of third research question concerning the roles that lecturer does in enhancing students' speaking performance. The data from those instruments were put forward systematically and accordingly to gain the comprehensive result of this research.

\section{FINDINGS AND DISCUSSIONS}

The data from students' journal were classified into students' learning strategies (1) direct strategies cover memory strategies, cognitive strategies, compensation strategies and (2) indirect strategies cover metacognitive strategies, affective strategies, and social strategies. The result showed that students frequently used memory strategies in their learning on speaking performance; it was used as the first rank with 24 as the frequency, and it was categorized as $2.88 \%$. The second rank of the strategies used by the students in speaking performance was metacognitive strategies with 18 as the frequency and it can can be categorized as $2.16 \%$. The third rank of the strategies used by the students in speaking performance was social strategies with 14 as the frequency, and it can be categorized as $1.68 \%$. Moreover, the fourth rank of the strategies used by the students was affective strategies with nine as the frequency, and it can be categorized as $1.08 \%$. Also, the fifth rank of the strategies was compensation strategies with 8 as frequency and can be categorized $0.96 \%$ followed by cognitive strategies in the sixth rank with three as frequency and can be categorized as $0.36 \%$. Learning strategies were affected and helped students to learn by using their own learning strategies which can make them aware to learn speaking. It can be presented by the table below that showed the occurrence of learning strategies were used by the students of the third semester of English Department in University of Muhammadiyah Sorong.

Table. 1 The Classification of Occurrence in Learning Strategies

\begin{tabular}{|c|c|c|c|c|c|c|c|}
\hline \multirow[b]{2}{*}{ SS } & \multicolumn{3}{|c|}{$\begin{array}{c}\text { Direct } \\
\text { Strategies }\end{array}$} & \multicolumn{3}{|c|}{$\begin{array}{c}\text { Indirect } \\
\text { Strategies }\end{array}$} & \\
\hline & 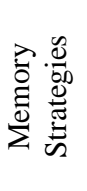 & 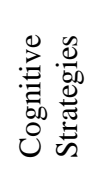 & 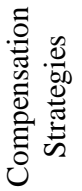 & 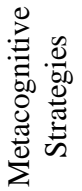 & 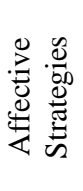 & 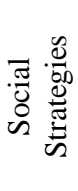 & 壳 \\
\hline
\end{tabular}

\begin{tabular}{cccccccc}
\hline S1 & $71 \%$ & $0 \%$ & $14 \%$ & $0 \%$ & $14 \%$ & $0 \%$ & $0.42 \%$ \\
\hline S2 & $50 \%$ & $0 \%$ & $15.5 \%$ & $15.5 \%$ & $15.5 \%$ & $15.5 \%$ & $0.48 \%$ \\
\hline S3 & $0 \%$ & $0 \%$ & $16 \%$ & $66 \%$ & $0 \%$ & $16 \%$ & $0.36 \%$ \\
\hline S4 & $0 \%$ & $0 \%$ & $33 \%$ & $50 \%$ & $0 \%$ & $16 \%$ & $0.36 \%$ \\
\hline S5 & $0 \%$ & $33 \%$ & $0 \%$ & $0 \%$ & $50 \%$ & $16 \%$ & $0.36 \%$ \\
\hline S6 & $0 \%$ & $16 \%$ & $0 \%$ & $33 \%$ & $0 \%$ & $50 \%$ & $0.36 \%$ \\
\hline S7 & $33 \%$ & $0 \%$ & $0 \%$ & $16 \%$ & $16 \%$ & $33 \%$ & $0.36 \%$ \\
\hline S8 & $66 \%$ & $0 \%$ & $16 \%$ & $0 \%$ & $0 \%$ & $33 \%$ & $0.36 \%$ \\
\hline S9 & $33 \%$ & $0 \%$ & $0 \%$ & $16 \%$ & $16 \%$ & $33 \%$ & $0.36 \%$ \\
\hline S10 & $50 \%$ & $0 \%$ & $0 \%$ & $33 \%$ & $0 \%$ & $16 \%$ & $0.36 \%$ \\
\hline S11 & $33 \%$ & $0 \%$ & $0 \%$ & $33 \%$ & $3 \%$ & $0 \%$ & $0.36 \%$ \\
\hline S12 & $16 \%$ & $0 \%$ & $16 \%$ & $50 \%$ & $0 \%$ & $16 \%$ & $0.36 \%$ \\
\hline
\end{tabular}

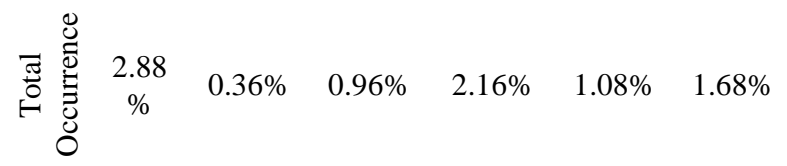

The other factors also influenced students learning strategies in learning speaking. As it showed by this findings that there were some factors influenced their learning strategies such psychological factor, a factor of the teacher, a factor of the task, a factor of environment and social factor. Furthermore, in enhancing students' speaking performance the teacher and lecturer also have roles in term of helping students to speak English. Therefore, the findings of this research showed the roles that the lecturer frequently did in enhancing students' speaking performance was feedback provider as the first rank. The second role that lecturer did in enhancing students speaking 
performance was as participant and followed by a prompter that the lecturer did in enhancing students' speaking performance.

The result revealed that students of the third semester at English department have a different way to learn to speak by applying their learning strategies. The data can be presented as follows:

1. Memory strategies:

"I also watched the movies which use English as the first language, and I also watched a tutorial video about speaking English on YouTube." (Student 8)

Based on the data above, it can be stated that student eight also used auditory and visual connection get some information to make her remember some vocabularies which make her easy to learn to speak. Therefore, it is briefly to state that student 8 used memory strategies in her learning.

2. Metacognitive strategies:

"I must prepare myself to believe that I can learn to speak and I must prepare dictionary to help me if I don't understand what the lecturer says, and also I must prepare the vocabulary for speaking every day." (Student2)

From the data above, it can be seen that student 2 tends to prepare and organize his learning concerning learning speaking. Therefore, it is briefly to state that student 2 tends to use metacognitive on his learning.

3. Social Strategies:

"Before learning speaking, I learned to speak alone or with friends as well although it is just greeting. She tries to practice with the other friends and discuss the last material before. If I get the problems in learning speaking I will ask more detail to the lecturer and to friends who know". (student 3).

From the data above, it can be seen that students 3 needs others in order to help her in learning speaking. She tries to involve her friends in discussing about the materials were given by the lecturer. Therefore, it is stated that student 3 tends to use social strategies in her learning.

4. Affective Strategies

"First, I prepare myself to be bravery to speak English in front of my friends and be self-confidence. Second, I prepare the material and prepare many vocabularies and I prepare myself for not being afraid and be brave to speak English with the lecturer". (student 5).

Based on the data above, student 5 tries to reduce her anxiety to learn speaking. She tries to learn speaking bravery by controlling her motivation wisely. It is briefly to state that student 5 tends to use affective strategies in learning speaking.

5. Compensation Strategies

"Write my daily activities and tell to my friends in front of the class, learning the exact location of conjunction. Learn about the tenses which are used to tell daily activities, practicing with friends before". (student 4).

From the data above, it can be seen that student 3 tends to learn speaking in specific topic or selecting topic. She tries to understand the appropriate grammatical contains the topic. It can be said that student 3 tends to use compensation strategies in learning speaking.

6. Cognitive Strategies

"I prepare myself for not being afraid when I ask a question to the lecturer and my friends. When I meet my friends, I also pay attention to the pronunciation of any speaking. I need to be brave and prepare myself." (student 6).

The data above shows that student 6 tries to prepare herself concerning the learning speaking. She tries to have big attention in understanding pronunciation. Therefore, it is briefly to state that students tend to use cognitive strategies. 
Based on the data above, it can be concluded that the learning strategies that used in speaking performance by the third semester of English Department at University of Muhammadiyah Sorong was in line with the theory which was proposed by Oxford (1990) that learning strategies consist of direct strategies; direct strategies cover memory strategies, cognitive strategies, and compensation strategies while indirect strategies cover metacognitive strategies, affective strategies, and social strategies.

\section{CONCLUSION}

Based on the first objective of the research was to identify the strategies are employed by students in enhancing their speaking performance, the researcher concludes that the primary strategies most frequently used by the students were memory strategies in their vocal performance. The students commonly use imagery and visual connection in their learning. The second strategies used by the students were metacognitive strategies. The students tend to plan, organize and set the goals of their learning. The third strategies used by the students were social strategies. In this strategy, the students asked for clarification from their friends, lecturer, and family. The fourth strategies used by the students were affective strategies. In this strategy the students decrease their anxiety, taking control of their emotion and using music in their learning. The fifth strategies used by the students were compensation strategies. This strategy indicated students to focus on their grammatical and selecting the topic. The sixth strategies used by the students were cognitive strategies. This strategy reflected the students to repeat the sound and focus on their pronunciation in learning speaking.

The second objective was to find out the factors influence students' learning strategies in enhancing their speaking performance; the researcher concludes that the factors influence students' learning strategies were a factor of psychology (learner themselves). This factor influences students' learning strategies. The second was the factor of the teacher; the teacher also plays an important role in enhancing students' speaking performance. The third was the factor of the task, the task that is given by the lecturer also influences students' learning strategies in enhancing their speaking performance. The fourth was the factor of the environment; students need the suitable environment to practice their speaking to make them active in speaking. The fifth was the social factor, in which the students asked for clarification to their lecturer, friends, and family concerning their learning to make understand.

Moreover, The third objective was to discover the roles the lecturer does in enhancing students' speaking performance; the researcher concludes that the first lecturer role in enhancing students' speaking performance was as a feedback provider. The lecturer most frequently used to be feedback provider to help students in enhancing their speaking performance. The second role of the lecturer in enhancing students' speaking performance was as a participant. The lecturer also participates directly to help students in enhancing their speaking performance. The third role of the lecturer was as a prompter. The lecturer helps the students in giving them motivation and raises their desire in enhancing their speaking performance.

\section{REFERENCES}

Brown, H. D. (2004). Language Assessment Principles and Classroom Practices. New York. Pearson Longman Education.

Chen, M-L. (2014). Age Differences in the Use of Language Learning Strategies. ELT Journal, 7(2), pp. 144-151, Retrieved on October 1, 2015, from www.ccsenet.org/elt 
Chamot, A.U. (1987). The Learning Strategies of ESL Students, in A. Weden and J. Rubin (eds) Learner Strategies in Language Learning, Hemel Hempstead: Prentice-Hall.

Ellis, G, and Sinclair, B. (1998). Learning to Learn English Cambridge. Cambridge University Press.

Gursoy, E. (2010). Investigating Language Learning Strategies of EFL Children for the Development of a Taxonomy. ELT Journal, 3(3), Retrieved on October 1, 2015, from www.ccsenet.org/elt

Harmer, J. (2001). The Practice of Language Teaching. Essex: Longman Press.

Jones, S. (1998). Learning Styles and Learning Strategies: Towards Learner Independence ELT for Modern Language Studies. Vol. xxx No. 2. Retrieved on August 25, 2015, from http://fmls.oxfordjournals.org/

Jamila, M. (2013). Use of Learner Autonomy in Teaching Speaking by Tertiary Level English Language Teachers in Private Universities of Bangladesh. ELT of IOSR Journal Humanities and Social
Science (IOSR-JHSS) Canadian center science and education Volume $18 \mathrm{Nov}$ Dec 2013.

Kemala, Z. (2014). An Analysis of Autonomous Learning Strategies Used By Senior High School Students. (Unpublished Thesis. Bandung UPI 2014)

Khotari, C. R. (2004). Research Methodology: Methods and techniques $\left(2^{\text {nd }}\right.$ revised edition). New Age International Publisher.

Nation, I.S.P. \& Newton, J. (2009). Teaching ESLEFL Listening and Speaking: ESL \& Applied Linguistics Series. The UK.

Oxford, R. L. (1990). Language Learning Strategies What Every Teacher Should Know. Newbury House.

Weinstein, C. and Mayer, R. (1986). The Teaching of Learning Strategies, in M. Wittock (ed.) Handbook for Research on Teaching, New York: Macmillan. in E. Macaro (ed).

Wenden, A. (1991). Incorporating learner training in the classroom, in A. Wenden and J. Rubin, Learner Strategies in Language Learning. Hemel Hempstead: Prentice-Hall 